\title{
CLIMATE CHANGES AND THEIR IMPACT ON CURRENT AND FUTURE THREATS TO THE PODKARPACKIE PROVINCE
}

\begin{abstract}
Currently, a forward-looking approach to threat assessment in a particular region is important. This approach applies especially to organizational units that are in the structure of offices at the basic level-the municipality, city and poviat. Currently, when generating hazard forecasts for a specific region, one focuses efforts mainly on objects or natural resources of the area (rivers, lakes, mountains, forests, factories, communication infrastructure), which are a potential source of threats (floods, fires, road collision, poisoning, etc.). This approach is a response to what is known but is unpredictable; such actions are rational and fulfill obligations related to ensuring security for the population. However, the approach does not sufficiently respond to the latest challenges faced by communities related mainly to climate change. Global warming intensifies the occurrence of existing threats and also brings new phenomena not encountered in a given area, such as drought, desertification of the area, and epidemics of new diseases. Based on the observations of the last 30-40 years, it follows that new phenomena has negative effects on the existence of the population and the economy of the region. Although warnings about the possibility of their occurrence are not new, such changes do not occur in a month or a year; they are often underestimated, and their consequences seem distant and remote. The purpose of the paper is to show, on the basis of examples of events that took place in the Podkarpackie Province, Poland and Europe, that for the security of the population in the region it is important to anticipate threats and implement services to counteract their effects.
\end{abstract}

Keywords: threat, warming, floods, epidemics.

\section{INTRODUCTION}

The Podkarpackie Province is located in the south-eastern part of Poland, borders on the east with Ukraine and the southern one is the border with Slovakia. Within the country, it borders with three provinces, from the west with Małopolskie, and in the north with Świętokrzyskie and Lublin. The area of the province is $17926 \mathrm{~km}^{2}$ where over 2 million people live (statistical year 2019). Administrative division includes 21 poviats, 4 cities with poviat rights and 160 municipalities. Within the province, several regions can be distinguished: mountainous in the south (the Bieszczady Mountains), highlands in the middle and lowland in the north (Sandomierska Basin). Several rivers flow through the Podkarpackie Province, including the Vistula River along the northern border, in addition:

\footnotetext{
${ }^{1}$ Fryderyk Czekaj, PhD, Rzeszow University of Technology, The Faculty of Management, Department of Humanities and Social Sciences, ul. Podkarpacka 1, 35-082 Rzeszów; e-mail: fczekaj@prz.edu.pl. ORCID: 0000-0002-3559-9194.
} 
San, Wisłoka, Wisłok, Jasiołka, Ropa, Breń, Tanew and several smaller rivers, which in certain situations may also pose a threat of flooding in specific regions of the region. The A4/E40 motorway, the S19 express road and 4 national roads run through the region. The density of poviat and municipality roads in the province is $36.2 \mathrm{~km} / 100 \mathrm{~km}^{2}$ and $44.7 \mathrm{~km} / 100 \mathrm{~km}^{2}$, respectively (Województwo podkarpackie, 2019). In the region there are 12 upper-tier establishments, 12 lower-tier ones and about 30 plants that can be potential industrial accident facilities. These plants produce, use or store chemicals that affect safety in individual poviats of the province. Dozens of objects are classified as critical infrastructure in 7 different systems (Ustawa, 2007, art. 3, pkt 2). The leading industry in the province is the aviation industry (Aviation Valley), which includes about 100 economic entities, as well as the raw material industry (sulfur, gas, oil).

Each area along with the infrastructure existing there is not free from all kinds of threats to people, animals or infrastructure. To properly understand this issue, it must be defined. A threat is a situation in which there is "an increased likelihood of losing life, health, freedom or material goods" (Leksykon, 1979). In turn, the Polish dictionary defines a threat as "a situation or condition that threatens someone or in which someone feels threatened" (Stownik języka polskiego). Considering only these two of many definitions, one can see that this concept has extremely subjective significance as it indicates both real existing situations causing a decrease or lack of security, as well as probable situations or even feelings that may have, for instance, an individual whose probability may even be faint. In further considerations we will focus on those threats that are real and probable. A crisisrelated category is a crisis situation which the legislator defined as "a situation adversely affecting the level of security of people, property of considerable size or the environment, causing significant restrictions in the operation of competent public administration bodies due to the inadequacy of the forces and resources possessed" (Ustawa, 2007, art. 3, pkt 1).

Security is another term closely related to the subject matter. there is no single definition that would comprehensively and unambiguously define what it is. This is due to its interdisciplinary nature, and its aspects are dealt with in many different fields of science, defining them differently. The differences in defining result from the dangers facing a man and societies. These threats have changed over the centuries. The first threats were related to the operation of nature and concerned the threat to life and functioning in the natural environment. Wild animals or the elements could kill a person, weather phenomena associated with drought or floods or other natural disasters destroyed crops and wreaked destruction. Along with the development of technology, some of these threats have been minimized, but others related to the development of civilization have arisen. A man himself began to pose threats to himself and the community (Czekaj, 2018). We often equate security with the lack of threats felt by an individual or group (Korzeniowski, 2005), or with the certainty that such threats do not occur (Ziemba, 2008).

Both provinces as well as the poviat or municipalities forming them differ significantly in terms of landformness and land cover. They are also distinguished by industrialization and equipment with technical infrastructure. Therefore, the threats occurring in different parts of the poviat are different and occur with varying intensity. To determine the scale of possible threats and the type and frequency of their occurrence, the observational and statistical methods were used, as well as document testing. These methods allow determining the types of threats that occur in individual poviats, their frequency, strength and predict potential consequences. 


\section{ADMINISTRATION BODIES RESPONSIBLE FOR CRISIS MANAGEMENT}

The central and local government administration in its structure at every level of functioning has organizational units (departments, centers, teams) dealing with the safety of the population living in the province (city, poviat, municipality). The task of crisis management department is to assess the threat in a given area and its impact on the security of the population living there. The threat to the population in a given area depends, in most cases, on natural resources, terrain and land cover, which includes rivers, lakes, forests, minerals (oil, gas etc.). However, the infrastructure created by people in a given area will have the significant impact on the type of threat, including: roads, workplaces, airports, dams on rivers. Everything that makes up the terrain of a given area and what the man has enriched this area can provide protection, help to function well or pose a threat to residents in certain conditions.

In preparation for counteracting possible threats at all levels of central and local government administration, a "Poviat (provincial, urban, municipal) crisis management plan" is being prepared, which is the attitude to take action in the event of a crisis. The basic plan data is the characteristics of a given administrative area in which it is exposed: geographical location, terrain, rivers and water bodies that are in a given area, gorges, landslides, wetlands, etc. An important element is the infrastructure of e.g. a poviat, including mainly road and rail network, airports, production plants, including facilities and equipment classified as critical infrastructure. Based on the quality and quantity of the infrastructure owned, the location of the poviat, there are assessed the threats that may occur in a given area both in a natural way in connection with extreme climate disasters and caused by human activities.

The location of a given poviat or municipality and its infrastructure may help people or intensify threat factors. The treats caused by natural forces will intensify in those poviats whose geographical location and land cover create such opportunities, e.g. flood - they occur in those poviats which rivers flow through or there are water bodies. The consequences of snowstorms are drifts, but they pose a special threat where roads run in ravines, etc. In some cases, the combination of terrain and infrastructure, such as regulated riverbeds, can generate hazards, such as floods. Other examples of threats are: fires, damage after the passage of a whirlwind, hurricanes, snowstorms, frosts in connection with moisture causing the accumulation of rime on electric wires. Hazards caused by human actions, lack of consideration can lead to fire or to intentionally starting fires. Reckless driving behavior is the cause of traffic accidents, and especially on expressways often leads to traffic cadastres (collisions). Lack of maintenance of public facilities or their misuse may lead to building or industrial cadastres etc.

In the Podkarpackie region, as many as 78 municipalities or parts thereof constitute areas at risk of flooding (Zarząd województwa, 2015). Most often this type of phenomenon occurs in the valleys of the Vistula, Wisłok, Wisłoka and San rivers. Flooding can also occur in mountainous and foothill areas. Another phenomenon causing threats are landslides, which are conducive to the terrain of the province, in particular its southern part. Deforestation, excessive development, increased traffic and activities resulting in undercutting of existing slopes contribute to the increased threat of this phenomenon. There is a threat of this type of threat in 81 municipalities in the province (Zarząd województwa, 2015).

At each level, crisis management plans include a safety net detailing likely hazards in the area and institutions and services responsible for their elimination. It can be assumed 
that individual crisis management units use a similar algorithm to analyze potential threats. First and foremost, the most probable and most common threats are identified, such as: floods, fires, snowstorms, storms and chemical pollution of the area. Subsequently; epidemic threats, technical failures, sometimes a terrorist attack is added.

\section{CLIMATE CHANGE AND NEW THREATS.}

The basic question that arises is whether these threats are permanent for a given area or can they change? The answer is unequivocal, by investing in the improvement of facilities posing a threat, we eliminate their negative impact and sometimes one can eliminate a specific threat. But is that all? - probably not! The new challenge is climate change - the warming it already has, and in the near future will have the greater impact on the threats of natural disasters caused by weather phenomena. Decades ago if one needed to find out if there was warming, they had to use scientific methods to prove it, and now people who remember the 70 s of the last century can easily compare them with the weather changes today to find out that warming is a fact. Some scientists claim that this is a stage of the natural cycle, but others say that apart from the cycle, the interference of a human being, which contributed to the increase in $\mathrm{CO}_{2}$ in the atmosphere and thus influenced the temperature increase, is not without significance. American climatologist Jonathan Cowie writes

"The climate of our planet is getting warmer, as well as numerous other phenomena: melting glaciers and ice sheets, faster sea level rise, climate zones and seasons shifting, freezing times of lakes, rivers and ports, more and more frequent heat waves, a decrease in the occurrence of cold days, an increase in air humidity or migration of animal species towards poles and up to sea level" (Cowie, 2009),

is one example that nature and animals are ahead of us in preparing to live in new conditions. Nicholas Stern assesses climate change in a similar way.

"An increase in global average temperature has the significant impact on the highest aspects of our natural environment, including water level, precipitation, strength and frequency of hurricanes and many more" (Sten, 2010).

Do these forecasts also apply to Europe, or far away countries in Africa, Asia, and Oceania? We have evidence that we also have weather anomalies recently (hurricanes, droughts etc.).

Similar phenomena can also be observed in Podkarpackie, average temperatures in the province are rising (measured at the meteorological station in Jasionka), in the years 19712000 the average temperature was $7.90^{\circ} \mathrm{C}$, in the period from 1991 to $2000-8.20^{\circ} \mathrm{C}$, between $2001-2010-8.70^{\circ} \mathrm{C}$, in 2018 it was already $9.90^{\circ} \mathrm{C}$ (Rocznik statystyczny, 2019). Along with other changes, this causes many areas to be at risk of drought.

Municipalities most endangered by soil drought: rural: Adamówka, Bojanów, Cmolas, Dzikowiec, Grębów, Harasiuki, Jarocin, Majdan Królewski, Niwiska, Rakszawa, Raniżów; urban and rural communes: Nowa Dęba, Nowa Sarzyna, Radomyśl Wielki, Sokołów Małopolski. Municipalities most endangered by hydrological drought, rural municipalities: Baligród, Besko, Bukowsko, Chorkówka, Cisna, Czarna (Bieszczady poviat), Dębowiec, 
Frysztak, Haczów, Horyniec-Zdrój, Jasienica Rosielna, Jasło, Jaśliska, Komańcza, Korczyna, Krempna, Krościenko Wyżne , Lubaczów, Lutowiska, Miejsce Piastowe, Nowy Żmigród, Olszanica, Osiek Jasielski, Ostrów, Solina, Tarnowiec, Wiśniowa, Wojaszówka, and Zarszyn; urban and rural municipalities: Brzozów, Dukla, Iwonicz-Zdrój, Jedlicze, Kołaczyce, Lesko, Narol, Rymanów, Strzyżów, Ustrzyki Górne, Zagórz; municipalities: Jasło, Krosno, Lubaczów (Zarząd województwa, 2015). The total number of communes at risk of this phenomenon is 59 , which is more than a third of all municipalities in the province [this is not synonymous with the surface - author's note].

Another more extreme manifestation is the desertification of part of our territory, especially in Wielkopolska, Kujawy and south-eastern Poland. Due to the lack of groundwater and a warmer climate, typical steppe vegetation was noticed in these areas. Marek Graniczny in his study states

"In southern and central Poland, the level of groundwater is low for natural reasons. It is further reduced primarily due to the lack of coherent water management and the exploitation of natural resources, especially lignite using the opencast method" (Graniczny, 2017).

Desertification is only a margin of nature, it's not an alarm yet, but one needs to take specific measures, makes decisions to stop further erosion of the earth. Ł. Kudlicki writes that

"the desertification (steppe) of Poland has been talked about not for today, but for over 50 years. Desertification, or rather dehydration (a mild form of this process), means, above all, soil degradation in dry, semi-arid soils with periodically dry areas, caused by various factors, including climatic and anthropogenic. Counteracting this phenomenon should include activities aimed at reclamation of partially degraded areas as a result of soil erosion, deterioration of its physical, chemical and biological properties, or long-term loss of natural vegetation" (Kudlicki, 2006).

The loss of productive land means the loss of pasture, efficient grain harvesting, lack of animal feed, and the result is fewer food products on the market and higher prices for us consumers.

One of the effects of less rainfall, lowering the level of groundwater and the lack of an adequate number of retention reservoirs outside drought is the reduction of potable water resources so necessary for the functioning of both humans and animals. Lack of water can be a huge strategic problem. A. Nowakowska-Kutra writes that

"at the macro-scale, access to potable water is a very important social problem. In Poland, it can be imperceptible and not experienced by many Poles. It is estimated that by 2030, two billion people in the world will not have access to clean water. This is one of the most important manifestations of the global polarization of the creation of the social world of poverty (understood inter alia as the inability to satisfy basic needs, including access to water) and on the other edge of wealth, understood here as luxury (...) access to clean water, but above all everyone drinking bottled water. As a result of the disturbance of the hydrological balance by the economy, seas and oceans are becoming increasingly polluted. The 
rivers are drying up and large rivers are polluted on an unprecedented scale: the Nile, the Yangtze River, holy for Hindus Ganges, (...) holy for Christians Jordan. The robbery of Israel and Jordan, struggling with the problem of access to fresh water, (...) has led to the fact that the great Jordan River, supplying water to people from the entire region, has turned into a stream in some places. (...) In Poland, in August 2012, the lowest level of the Vistula was recorded in six hundred years" (Nowakowska, 2014).

An extensive action in this area is necessary. It would seem that this is rather a task related more to environmental protection or water management, and to a much lesser extent to crisis management. We can think so until the time when due to hot weather there is not enough potable water for the inhabitants, and high temperatures will favor fires that will not be extinguished. From this moment it will be a crisis situation requiring immediate action and mobilization of resources accumulated in this case.

An increase in average temperatures and longer periods of drought do not exclude a phenomenon that appears to be in conflict with the first two, namely floods. In addition to the periodic flooding that we observe every year, we also deal with phenomena of a much larger scale. One of the biggest floods took place in 1997 and covered the Odra River together with tributaries in the Czech Republic, Poland and Germany. M. Graniczny and W. Mizerski write that

"Heavy rainfall 3-8 VII 1997 caused that already on July 7, the first villages and towns were flooded by Bila (the Czech Republic and Nysa Kłodzka. Jeseniki, Kłodzko, where four hundred-year-olds collapsed, were under water. Large urban agglomerations and areas adjacent to them on both sides of the Polish-German border were also victims of the flood on the Odra River. Racibórz, Opole Wrocław nearly half the city was flooded), (...) water level at the mouth of Mała Panew near Opole July 10.11 and Odra amounted to $733 \mathrm{~cm}$ and flow $3500 \mathrm{~m}^{3} / \mathrm{s}$, while the average long-term flow in this place is forty-two times less $\left(82.5 \mathrm{~m}^{3} / \mathrm{s}\right)$ and the average water level over $5 \mathrm{~m}$ lower $(213 \mathrm{~cm})$ " (Graniczny, 2009).

Podkarpacie was also affected by floods, the Wisłoka and Breń rivers flooded at the mouth of the Vistula River, as a result of which the towns in Czermin and Borowa municipalities from the Podkarpackie Province were flooded. The neighboring provinces whose poviats currently belong to the Podkarpackie also fought against the flood at that time. Most of the rivers flowing through Podkarpacie have their sources in the mountains and with heavy rainfall in the upper rivers, flooding in the central part of the Podkarpackie Province is certain. This is due to the fact that in the upper course of the rivers the bed base is stony and streams along stony slopes quickly supply water to rivers and its excess is the cause of floods. If for several years we have observed violent storms, during which it falls to several tens of $\mathrm{cm}$ of rain per $\mathrm{m} 2$, then probable catastrophic floods are almost certain. The balance of catastrophic flood losses for Central Europe, according to M. Graniczny and W. Mizerski, was as follows:

"The summary flood balance is:

-55 fatalities

- 200,000 people evacuated

- 2592 flooded towns, including 1362 completely 
- 480 bridges destroyed, over $1370 \mathrm{~km}$ of roads and 1,100 km of flood embankments" (Graniczny, 2009).

In subsequent years, floods did not bypass the Podkarpackie region, especially the 2010 flood, which covered several poviats of the province. The most affected poviats were: Mielec Tarnobrzeg, Stalowa Wola, Jasło, Przemyśl, Rzeszów, Ropczyce and Sędziszów. It was a catastrophic flood exceeding in all respects considered the 1997 flood. This is one of the next phenomena that we will probably have to deal with more often. Unexpected and devastating catastrophes caused by extreme weather phenomena (natural disasters, earthquakes, epidemics of infectious diseases of humans and animals) appear more and more often. J Cowie on climate change writes that

"Changes in the future may be practically quite small, with only a marginal surplus over previous cases. The problem is that the flood is a catastrophic event. Small changes can bring great results. Things are fine as long as there are no breaches in the flood embankments. But if the peak of the wave rises by just a few millimeters, catastrophic changes can occur. We expect an increase in the number of major floods in Europe, despite the fact that summer is expected to be drier. It seems paradoxical, but computer models predict an increase in intense summer rainfall and global warming. Instead of smaller rain evenly distributed throughout the summer months, we can expect a tendency to rarer extreme downpours" (Cowie, 2009).

The created warning system and the forces dedicated to the rescue operation are ready for action. However, it should be remembered that subsequent weather anomalies can be more catastrophic than previous ones.

Each latitude can be attributed to specific diseases that attack the population at appropriate times of the year, and this part with weaker immunity is more difficult to fight the virus or even dies, but it is statistically a small group of people. Some of them, apart from a periodic increase in the incidence, lead to local epidemics, and specialized services deal with this problem well. It's worse when we are harassed by viruses that cause illnesses or animal epidemics. Examples of this could be swine or bird flu, African swine fever, or mad cow disease. Rapid intervention of specialized services is able to protect the population against the epidemic, so far zoonoses have not spread to humans on a large scale. But will it always be this way? It has been pointed out for several years that the change in weather (warming) is poisoned by the occurrence of increasingly frequent periodic illnesses. J. Cowie writes:

"The summer increase in the number of cases of food poisoning in the temperate zone suggests that in a warmer world there may be even more. WHO and the UN for Food and Agriculture have estimated that at least 2 billion people get food poisoning each year and some of them die. (...) As a result of climate change, the seasonal course of Lyme disease (Lyme disease) may also change" (Cowie, 2009).

In addition, globalization means that phenomena, including diseases originating in one region of the world, can move to the opposite end in one day. Malaria also goes to our temperate zone, which we attribute to a warmer zone on Earth, but with warming, it knocks 
at our door. We know today that viruses have no boundaries or distances fighting coronavirus. Scientists wrote about the possibility of this type of pandemic a few years ago.

\section{CHALLENGES FOR CENTRAL AND LOCAL GOVERNMENT ADMINISTRATION}

It's time for the Crisis Management units to try to identify new challenges - threats to be prepared for. It should be assumed that the existing threats will continue to occur, however, some of them will occur with extreme severity and rapid course, forcing a new approach and seeking new ways of dealing with. In turn, completely new ones are those that have not previously occurred in a given area, e.g. prolonged drought turning into desertification in some areas, increased appearance of various pests of agricultural and pathogenic crops (Colorado beetle, ticks), increased migration of population caused by climatic and economic factors, epidemics.

These threats are so serious that both states and international organizations are verifying existing security strategies as part of the fight against new threats. An example would be the actions taken by the European Union to reduce the negative effects of $\mathrm{CO}_{2}$ emissions. Tomasz Młynarski writes, quoting Norman Mvers,

"that national security is not only about warring armies and armaments, but increasingly refers to access to water resources, arable land, forests, biodiversity resources, climate, and other factors rarely considered by military experts and political leaders" (Młynarski, 2017).

Crisis management units should face a problem to be resolved, where to get water for people and animals during drought and scarcity. This is no longer a temporary suspension of the use of existing waterworks due to the detection of harmful microorganisms that will recover after disinfection, but the lack of water from existing sources of supply. One needs to look for spare water sources in their territory, e.g. (construction of retention reservoirs, limiting river channel regulation only to places where it is necessary), construction of artesian wells, old rural wells that need to be cleaned and supervised, mineral water sources, such which from an economic point of view is not profitable but can prove useful in a crisis. These are just a few examples that can help in extreme situations, but you should not postpone the matter, because the need may be in a few months or several years. One should not forget about education related to saving water every day.

How to prepare for great pandemics like in the case of coronavirus? The current situation of the world in the fight against coronavirus is a powerful experimental field that exposes the lack of material resources to protect the population against the virus. Lack of procedures for the basic organizational units responsible for protecting the population in the event of a non-military threat. If we draw conclusions from this and prepare crisis institutions for an action in situations of non-military threat and sometimes even more dangerous than military ones, such as unknown viruses or pathogenic bacteria, then each subsequent pandemic will have a mild and controlled course for humanity.

Can cyber threats really threaten people's life and health? Is it possible to predict new threats, and if not how to prepare for flexible response to the unexpected. This is certainly a challenge for the services responsible for security and crisis management in the near future. 


\section{REFERENCES}

Cowie, J. (2009). Zmiany klimatyczne. Warszawa: Uniwersytet Warszawski.

Czekaj, D. (2018). Wojsko a społeczność lokalna - wzajemne relacje. Studium przypadku na przyktadzie 21. Brygady Strzelców Podhalańskich. Rozprawa doktorska niepublikowana. Rzeszów: Uniwersytet Rzeszowski.

Graniczny, M., Mizerski, W. (2009). Katastrofy przyrodnicze. Warszawa: Wydawnictwo Naukowe PWN.

Graniczny, M. (2017). Zagrożenia. Warszawa: Wydawnictwo Naukowe PWN.

Korzeniowski, L. (2005). Obiektywne a subiektywne kategorie bezpieczeństwa narodowego [w:] Maciejewski, J., Nowaczyk, O., red., Bezpieczeństwo narodowe a grupy dyspozycyjne. Wrocław: Wydawnictwo Uniwersytetu Wrocławskiego.

Kudlicki, Ł. (2006), Zagrożenie pustynnieniem w Polsce. „Bezpieczeństwo Narodowe”, nr 1.

Leksykon wiedzy wojskowej (1979). Warszawa.

Młynarski, T. (2017). Bezpieczeństwo energetyczne a ochrona klimatu w drugiej dekadzie XXI wieku. Kraków: Wydawnictwo Uniwersytetu Jagiellońskiego.

Nowakowska-Kutra, A. (2014). Woda w butelce - analiza socjologiczna. „Kultura i Spoteczeństwo", nr 2.

Obszary funkcjonalne $w$ województwie podkarpackim, (2015), załącznik do uchwały nr 86/199715 zarządu województwa podkarpackiego z dnia 25.08.2015 r., Rzeszów.

Rocznik Statystyczny Województwa Podkarpackiego, (2019). Rzeszów, Urząd Statystyczny w Rzeszowie.

Stownik języka polskiego PWN. https://sjp.pwn.pl.

Stern, N. (2010). Globalny ład, Zmiany klimatu a powstanie nowej epoki postęu i dostatku. Warszawa: Wydawnictwo Krytyki Politycznej.

Ustawa z dnia 26 kwietnia 2007 r. o zarządzaniu kryzysowym (Dz.U. z 2007 r., nr 89, poz. 590 ze zm.).

Województwo Podkarpackie. Podregiony, Powiaty, Gminy, (2019). Rzeszów, Urząd Statystyczny w Rzeszowie.

Ziemba, R., red., (2008). Bezpieczeństwo międzynarodowe po zimnej wojnie. Warszawa: Wydawnictwa Akademickie i Profesjonalne.

DOI: $10.7862 /$ rz.2020.hss.13

The text was submitted to the editorial office: April 2020.

The text was accepted for publication: June 2020. 
